\title{
RETROSPECTIVE STUDY ABOUT THE TRANSFORMATION OF DAIRY CATTLE POPULATION IN TURKEY (1991-2019) AND POSSIBLE METABOLIC AND REPRODUCTIVE PROBLEMS
}

\author{
Kemal AKSOY ${ }^{*}$, Abdülkerim DENIZ², Mert METIN ${ }^{3}$ \\ ${ }_{1}^{1}$ Mugla Sitki Kocman University, Faculty of Veterinary Medicine, Department of Internal Medicine, 48210, Milas, Mugla, Turkey \\ ${ }^{2}$ Free Researcher, İstanbul, Turkey \\ ${ }_{3}^{3}$ Mugla Sitki Kocman University, Faculty of Veterinary Medicine, Department of Biochemistry, 48210, Milas, Mugla, Turkey
}

\begin{abstract}
The present study analyzed the transformation of dairy cattle population and changes in yearly milk production and per lactation milk yield (1991 - 2019) in Turkey. In addition, metabolic and reproductive diseases frequently seen in high milk yielding dairy cows (HYDC) and problems causing low milk yield were investigated. The number of dairy cows, culled and sent to slaughter was investigated for the last three years in Turkey. On the other side, the cost of the most common metabolic diseases by region has been analyzed by a phone survey (40 vets were asked in different regions). The dairy cow population was 6118997 in 1991 (HYDC pure breed: $10.6 \%$ and traditional indigenous dairy breed: 55.3\%). The dairy cow population reached 6580753 in 2019 (7.5\% increase compared to 1991) which consisted of pure breed HYDC of 49.4\% and traditional dairy breed of $8.9 \%$. This is a transformation in dairy cattle population in 28 years. Yearly total milk production increased by $141.2 \%$ from 8.616 .412 tons (1991) to 20782374 tons (2019). Yearly milk production per lactation/cow increased from 1.4 tons (1991), to 1.65 tons (2000) and to 3.16 tons (2019) which means $17.5 \%$ and $124.3 \%$ increase, respectively. The growth of the number of HYDC pure breed and their total yearly milk production was $399.3 \%$ (650739 - 3249002) and 555.6\% (1913438 tons to 12544507 tons) in 28 years, respectively. Numerous metabolic and reproductive diseases can often be observed in HYDCs due to genetic reasons as well as nutritional and maintenance mistakes during the transition and dry period which can cause economic loss related to milk yield and metabolic diseases. The treatment cost of the metabolic or reproductive diseases for the farmers was between 150-1200 TL per case. Many of the animals were sent to compulsory slaughter and culled because of these diseases. Indeed, a total of 738681 dairy cows have been sent to slaughter throughout the last three years.
\end{abstract}

Keywords: Dairy population, Milk yield, Metabolic diseases, Cost of diseases, Turkey

\begin{tabular}{|c|c|c|}
\hline \multicolumn{3}{|c|}{$\begin{array}{l}\text { *Corresponding author: Mugla Sitki Kocman University, Faculty of Veter } \\
\begin{array}{ll}\text { E mail: kemalaksoy@mu.edu.tr (K. AKSOY) } \\
\text { Kemal AKSOY } & \text { (iD) https://orcid.org/0000-0003-0149-6688 }\end{array}\end{array}$} \\
\hline Abdülkerim DENiZ & https://orcid.org/0000-0002-5242-5671 & Accepted: December 27, 2020 \\
\hline Mert METIN & https://orcid.org/0000-0002-1402-4594 & Published: May 01, 2021 \\
\hline
\end{tabular}

Cite as: Aksoy K, Deniz A, Metin M. 2021. Retrospective study about the transformation of dairy cattle population in Turkey (1991-2019) and possible metabolic and reproductive problems. BSJ Health Sci, 4(2): 77-84.

\section{Introduction}

The dairy cattle population and milk production show rapid development in the world, especially in developing countries, as well as in Turkey (TİGEM, 2017; TÜİK, 2019). Dairy cattle husbandry and milk production in Turkey is primarily executed in the style of small family business (Vural and Fidan 2007), which is of great importance in terms of rural development. Since 2002, the dairy cattle population has undergone a significant transformation and low milk yielding indigenous breeds have been replaced by high-yielding dairy pure and culture breeds. Thus, the volume of milk produced annually increased with the same number of dairy cattle (TÜIK, 2019). Milk production per animal in lactation is high in Turkey compared with the average milk yield per cow in the world, but it is still relatively low compared to other EU countries (TIGEM, 2017). However, some problems arise with this transformational change. In addition to the high milk yield of the pure and culture breeds compared to indigenous breeds, the incidence of disease and maintenance costs are higher. Especially in Holstein dairy cows, post-partum milk fever, ketosis, abomasal displacement, downer cow syndrome, liver fatty diseases are common. In the first 6 weeks of the lactation, when the lactation reaches the peak, the energy deficit (negative energy balance, NEB) occurs in dairy cows, where the energy requirement is not met sufficiently. Consequently, lipid mobilization starts, which ends up with ketosis. Correa et al. (1993) demonstrate that dairy cows are linked to clinical ketosis and diseases such as metritis, abomasum displacement, and mastitis. Besides, some researchers (Dohoo and Martin, 1984; Whitaker et al., 1993) report that subclinical ketosis is associated with decreased milk yield, increased risk of post-partum diseases such as clinical ketosis, metritis, cystic ovaries, reduced reproductive performance, and other disorders. It is also reported that cattle foot diseases are more common in 
culture pure breeds compared to indigenous breeds. The reason is that the culture breeds having more bodyweight than indigenous breeds and cross-breeds, other reasons are high milk yield characteristics and more susceptible to diseases in Turkey. Some studies were conducted in Turkey in order to determine the prevalence of foot diseases in different regions. Foot disease in culture breeds was found to be more frequent than in the indigenous breeds (İstek and Durgun, 2004; Özcan and Pamuk, 2009; Ünsaldı and Durmuş 1999; Yayla et al., 2012; Yurdakul and Şen, 2018; Yakan, 2018). In the study of Görgül (1988), the distribution of foot lesions among breeds was determined by $69.52 \%$ in Holstein, $24.76 \%$ in Montofon, $0.95 \%$ in Jersey, $1.92 \%$ in indigenous breeds, $2.85 \%$ in hybrid cows. İstek and Durgun (2004) reported that Holstein, Simental, Montofon, hybrid cows and indigenous breeds had foot lesions by $23.13 \%, 19.56 \%, 14.74 \%, 12.20 \%$, and $10.26 \%$ respectively. The present study analyzed the transformation of dairy cattle population, changes in yearly and per lactation milk production (1991-2019) in Turkey based on data received from the internet web page of Turkish Statistic Institute and Turkish General Directorate of Agricultural Enterprises (TÜIK, 2019; TİGEM, 2019).

In this study, metabolic and reproductive diseases frequently seen in high milk yielding dairy cows (HYDC) and problems causing low milk yield were investigated. It is thought that cows with high milk yield go to slaughter at an early age and have a higher risk of getting metabolic diseases. This situation brings serious treatment costs for farmers. The number of dairy cows which were culled and sent to slaughter across the provinces in Turkey between 2017 - 2019 was investigated. Medical expenses of the most common metabolic diseases were calculated by region by a survey which was carried out with vets by phone.

\section{Material and Methods}

\subsection{Dairy Cattle Statistics between 1991 and 2019}

The number of dairy cows and the quantity of yearly milk production for each breed (1991 - 2019) were investigated by using the information received from the internet web page of the Turkish Statistic Institute (TÜIK, 2019) and the Turkish General Directorate of Agricultural Enterprises (TIGGEM, 2019).

The growth rates and changes of animal numbers and milk yield by years (initial value-1991, final value-2019) were calculated according to the formula (final valueinitial value) $\mathrm{x} 100 /$ initial value. The growth rates and changes were presented in numbers and percentage. Metabolic and reproductive diseases frequently seen in high milk yielding dairy cows (HYDC) and problems causing low milk yield were investigated by using the literature review. The data obtained from different sources are presented in graphical and numerical charts.

BSJ Health Sci / Kemal AKSOY et al.
2.2. Treatment Costs of Postpartum Metabolic and

\section{Reproductive Diseases}

Forty veterinarians in 10 provinces of Turkey (Afyon, Kars, Konya, İzmir, Urfa, Antalya, Edirne, Muğla, Tokat, Zonguldak) were randomly chosen and asked by a phone survey about the average cost of the treatment for laminitis, metabolic (abomasal displacement, ketosis) and reproductive diseases (retained placenta, metritis, mastitis, cystic ovarian disease, artificial insemination) for farmers. Provinces were divided into 2 groups according to the number of lactating dairy cows in 2019. Group 1 represents provinces (Afyon, Kars, Konya, İzmir, Urfa) with over 120000 lactating dairy cows. Group 2 represents provinces (Antalya, Edirne, Muğla, Tokat, Zonguldak) with less than 120000 lactating dairy cows.

2.3. Number of Female Animals Culled and Sent to Slaughter by Provinces between 2017 and 2019

The numbers of female cattle, which were culled and sent to slaughter, were received from the Turkish Ministry of Agriculture and Forestry in response to the official letter related to the present study. The incoming raw data were arranged for the descriptive statistic in the excel file.

\subsection{Statistical Analysis}

The growth rates and changes in the animal numbers and milk yield by years (initial value-1991, final value-2019) were calculated according to the formula (final valueinitial value) $\times 100 /$ initial value. The growth rates and changes were presented in numbers and percentages. SPSS (SPSS 20.0 Software Package Program Inc., Chicago, Illinois, USA) was used to statistical analysis of diseases treatment costs. Mann-Whitney $U$ test was used to compare treatment costs between cities (group 1 and group 2). Descriptive statistic was used for the number of animals, milk production and number of female animals culled and sent to slaughter by provinces between 2017 2019.

\section{Results}

\subsection{Transformation of Dairy Cattle Population in} Turkey

When examined both breed distribution of dairy cows and the quantity of annual milk production from 1991 to 2019 in Turkey, there has been a transformation, especially after 2002. According to the information from TÜIK (2019), the number of dairy cows raised from 6118997 in 1991 to 6580753 in 2019 in Turkey, which means a growth of $7.5 \%$ and 461756 in absolute value in 28 years only (Figure 1 ).

When looked at the human population change concerning milk demand and consumption in the roughly same period, the population of Turkey was 56473035 and 82003882 in 1990 and 2018, respectively. This means an increase of approximately $45 \%$ and does require either an increase in milk production or dairy population to meet the requirement of the population.

However, the number of dairy cows did not proportionally increase between 1991 - 2019, but yearly total milk production raised from 8616412 tons to 
20782374 tons, which means $141.2 \%$ increase (Figure 2). This significant increase was because that only $10.6 \%$ of dairy cow population was pure culture HYDC breeds in
1991 and it raised to $49.4 \%$ in 2019 with a respective increase of milk yield per lactation (124.3\% increase).

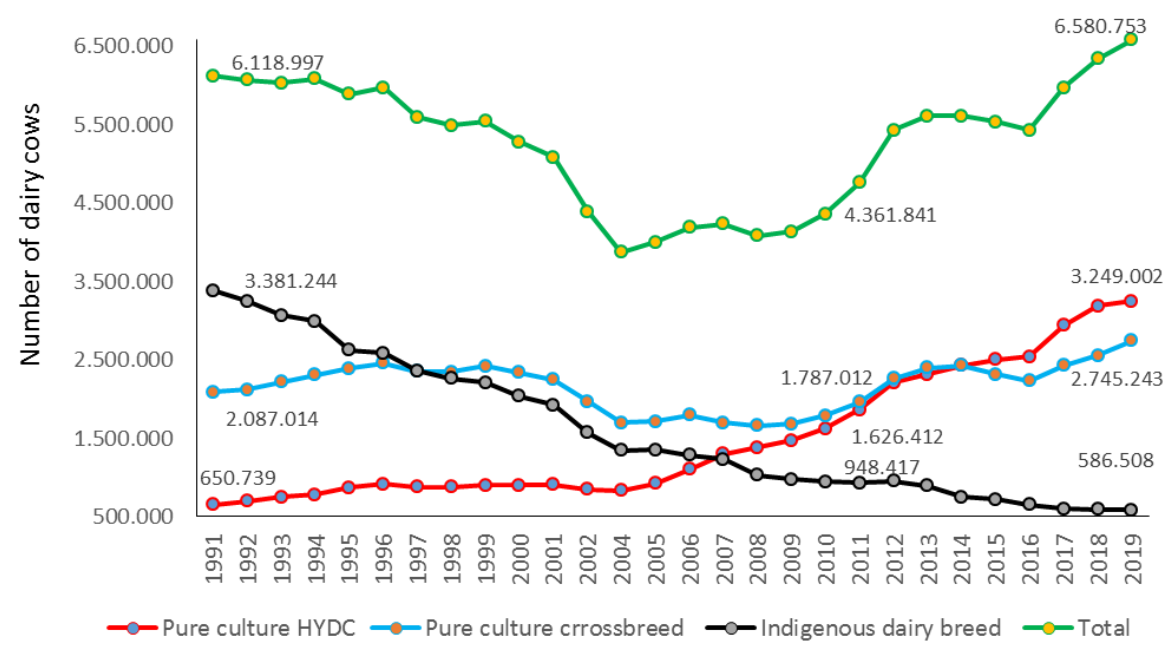

Figure 1. Change of dairy cattle population between 1991 and 2019 in Turkey.

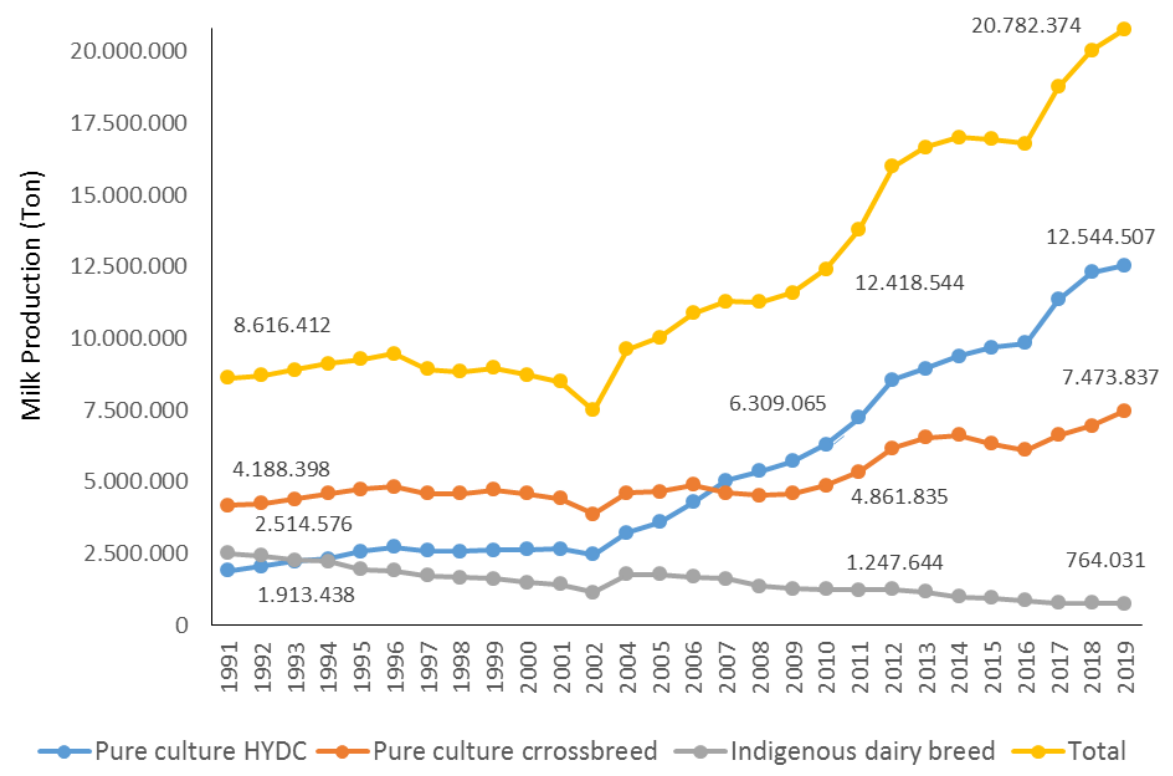

Figure 2. Change of annual milk production between 1991 and 2019 in Turkey.

The majority $(55.3 \%)$ of the dairy population was indigenous dairy breeds with low milk production in 1991 (0.74 tons per lactation), however due to the transformation in dairy cow population breeds in the last 28 years, the majority of the dairy cow population became pure breed HYDC with $49.4 \%$ proportion among others in 2019 (Figure 1). When the number of domestic milking, pure breed HYDC and culture cross-breed dairy cows were examined between 1991 and 2019, the number of domestic milking cows decreased from 3381244 to 586508 while the number of pure breeds dairy cows increased from 650739 to 3249002 . The number of pure culture crossbreed dairy cows increased from 2087014 to 2745243 . Therefore, in the last 28 years Turkey's dairy cows' population changed from low milk producing domestic breed to pure breed HYDC and crossbreeds, which means a transformation in the dairy cow population (Figure 1). The transformation in the dairy cow population was accelerated, especially after 2000 . Between 2000 and 2019, the growth in the number of pure breeds HYDC reached 259\%, while the total annual milk production increased by $138 \%$ from 8732041 tons to 20782374 tons (Figure 2). The annual amount of milk produced in one lactation per animal increased from an average of 1.41 tons in 1991 to 1.65 tons in 2000 and to 3.16 tons in 2019 , approximately $124.3 \%$ increase in 28 years (Table 1). The effect of increased number of HYDC on the total annual milk production for the years of 1991, 2000 and 2019 was summarized in Figure 3. Although there has not been a considerable increase in the total 


\section{Black Sea Journal of Health Science}

dairy cows' population in the past 28 years (Figure 1), the replacement of the indigenous dairy breed population with the pure culture HYDC breed has led to a remarkable increase of the annual milk production in Turkey. Milk production per lactation per cow (3.1 tons) in Turkey (average 305 days) became higher than the world average (2.4 tons) and lower than EU countries (6.7 tons) and Western European countries (7.4 tons). Besides, milk production per animal per lactation in TİGEM $(7485 \mathrm{~kg})$ is competing with Western European countries (TIGEM, 2017) (Figure 4).

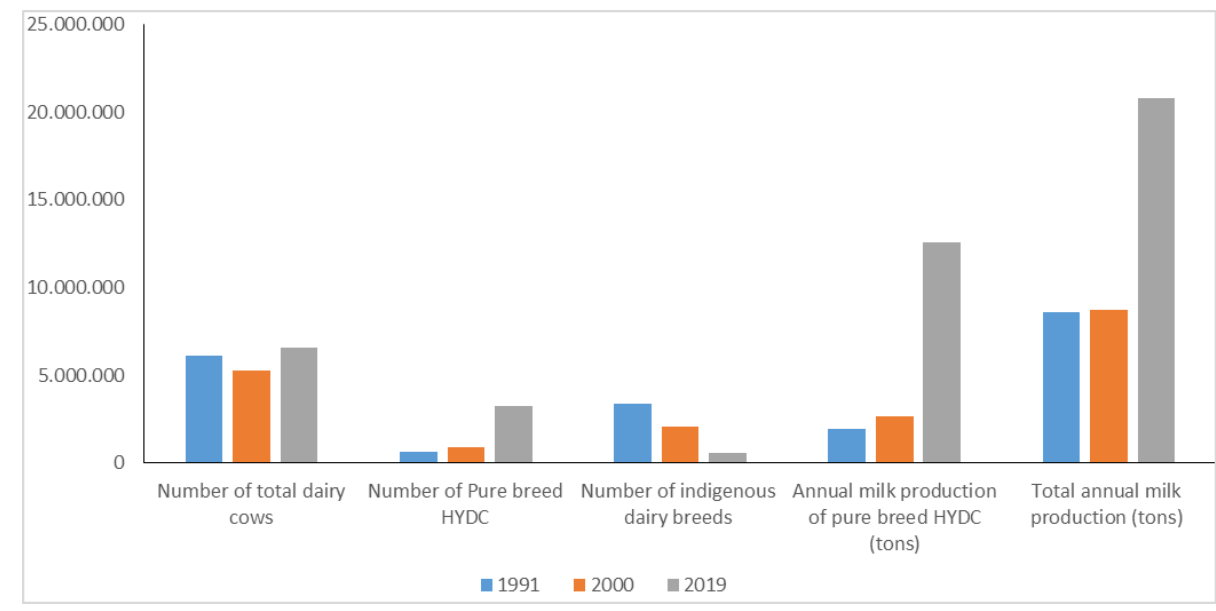

Figure 3. Summary for the change of dairy cow number and milk production in the years of 1991, 2000 and 2019.

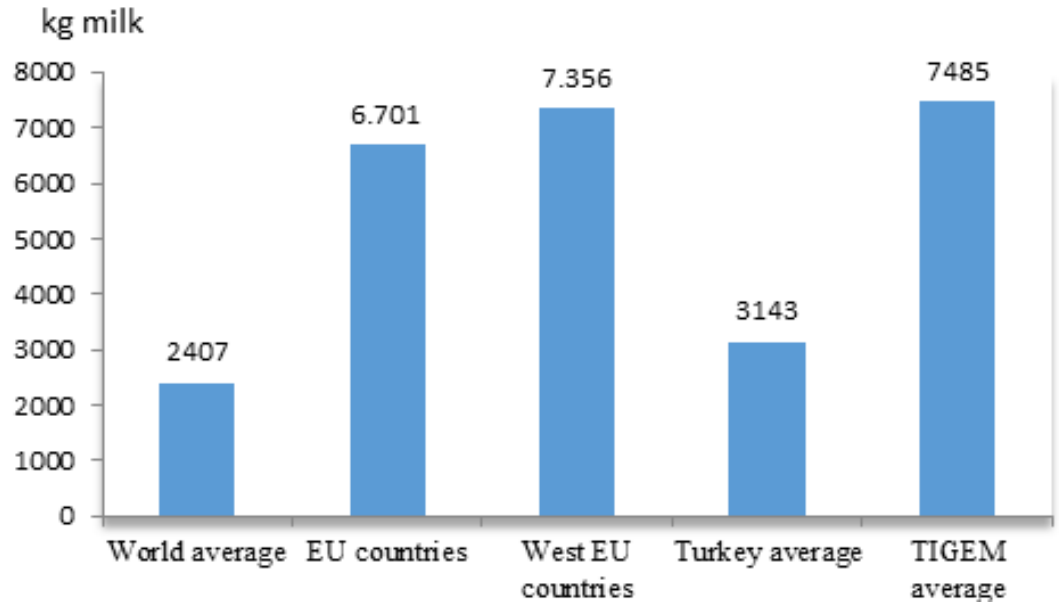

Figure 4. Milk yield per lactation per cow (TİGEM 2017).

Table 1. Milk production per lactation in different dairy breeds and its growth based on 1991 value as initial (Remark: Volume (ton) per lactation per cow was calculated by dividing the total milk yield with the respective number of lactating animals)

\begin{tabular}{ccccccccc}
\hline & \multicolumn{2}{c}{ Average total } & \multicolumn{2}{c}{ Pure breed HYDC } & \multicolumn{2}{c}{$\begin{array}{c}\text { Culture crossbreed } \\
\text { dairy cows }\end{array}$} & \multicolumn{2}{c}{ Indigenous dairy breeds } \\
\hline & Volume (ton) & $\begin{array}{c}\% \\
\text { growth }\end{array}$ & $\begin{array}{c}\text { Volume } \\
\text { (ton) }\end{array}$ & $\begin{array}{c}\% \\
\text { growth }\end{array}$ & $\begin{array}{c}\text { Volume } \\
\text { (ton) }\end{array}$ & $\begin{array}{c}\% \\
\text { growth }\end{array}$ & $\begin{array}{c}\text { Volume } \\
\text { (ton) }\end{array}$ & \% growth \\
\hline 1991 & 1.41 & 0 & 2.94 & 0 & 2.01 & 0 & 0.74 & 0 \\
2000 & 1.65 & 17.45 & 2.92 & -0.81 & 1.97 & -2.02 & 0.73 & -1 \\
2010 & 2.85 & 102.19 & 3.88 & 31.92 & 2.72 & 35.6 & 1.32 & 77 \\
2019 & 3.16 & 124.27 & 3.86 & 31.31 & 2.72 & 35.7 & 1.30 & 75 \\
\hline
\end{tabular}

\subsection{Most Common Metabolic Diseases and Treatment Costs in HYDC}

Table 2 presents the average cost of each metabolic and reproductive disorder in the provinces. Overall treatment cost of the diseases for the farmers was the lowest in Kars province. The lowest treatment cost for the abomasum displacement was 400 TL in Kars (Group 1), and the highest cost was $1175 \mathrm{TL}$ in İzmir (Group 1). Clinical ketosis treatment cost was observed between $180 \mathrm{TL}$ and $600 \mathrm{TL}$ in different provinces. The treatment cost for laminitis was between $80-430 \mathrm{TL}$, while the cost of metritis treatment was between 100-600 TL. The cost 
of retained placenta treatment was observed between 150-400 TL. Mastitis treatment cost varied between 150 and $650 \mathrm{TL}$, and cystic ovaries treatment varied between 100-350 TL. One-time artificial insemination application cost between 60-300 TL for the farmers in 10 different provinces. Provinces were divided into two with regard to their dairy population < or $>120000$. Afyon, Kars, Konya, İzmir and Urfa were allocated to group 1 (>120000), while Antalya, Edirne, Muğla, Tokat and Zonguldak were allocated to group $2(<120000)$.

Table 2. Average treatment costs of most common metabolic diseases in high milk yielding animals (Turkish Lira)*

\begin{tabular}{|c|c|c|c|c|c|c|c|c|c|}
\hline \multirow{3}{*}{ Groups } & & $\mathrm{AD}$ & Clinic ketosis & Laminitis & Metritis & $\mathrm{RP}$ & Mastitis & $\mathrm{CO}$ & $1 \times \mathrm{AI}$ \\
\hline & Provinces & & & & & & & & \\
\hline & Afyon & $825 \pm 350$ & $325 \pm 87$ & $263 \pm 48$ & $225 \pm 61$ & $225 \pm 29$ & $250 \pm 73$ & $200 \pm 58$ & $120 \pm 0$ \\
\hline \multirow{6}{*}{$\begin{array}{l}\text { G-1 } \\
>120000 \\
\text { lactating } \\
\text { dairy cows }\end{array}$} & Kars & $475 \pm 87$ & $233 \pm 54$ & $213 \pm 48$ & $175 \pm 65$ & $275 \pm 65$ & $275 \pm 65$ & $150 \pm 20$ & $225 \pm 65$ \\
\hline & Konya & $700 \pm 41$ & $525 \pm 132$ & $300 \pm 71$ & $288 \pm 25$ & $150 \pm 0$ & $325 \pm 65$ & $153 \pm 5$ & $110 \pm 12$ \\
\hline & Izmir & $1175 \pm 171$ & $275 \pm 29$ & $145 \pm 33$ & $350 \pm 71$ & $188 \pm 25$ & $200 \pm 41$ & $100 \pm 0$ & $133 \pm 15$ \\
\hline & Urfa & $500 \pm 0$ & $325 \pm 50$ & $313 \pm 48$ & $288 \pm 25$ & $275 \pm 87$ & $275 \pm 29$ & $238 \pm 75$ & $225 \pm 50$ \\
\hline & Average G-1 & $735 \pm 68.5^{*}$ & $336.5 \pm 27.8$ & $246.5 \pm 17.4$ & $265 \pm 17.3$ & $222,5 \pm 15.2^{*}$ & $265 \pm 14.6^{*}$ & $168 \pm 13.8$ & $162.5 \pm 13.9$ \\
\hline & Antalya & $750 \pm 58$ & $388 \pm 48$ & $388 \pm 25$ & $263 \pm 25$ & $263 \pm 25$ & $313 \pm 25$ & $200 \pm 0$ & $184 \pm 42$ \\
\hline \multirow{6}{*}{$\begin{array}{l}\text { G-2 } \\
<120000 \\
\text { lactating } \\
\text { dairy cows }\end{array}$} & Edirne & $963 \pm 75$ & $538 \pm 210$ & $260 \pm 113$ & $313 \pm 75$ & $305 \pm 6$ & $380 \pm 0$ & $150 \pm 0$ & $126 \pm 5$ \\
\hline & Muğla & $900 \pm 115$ & $300 \pm 71$ & $263 \pm 85$ & $450 \pm 100$ & $250 \pm 71$ & $500 \pm 122$ & $125 \pm 29$ & $158 \pm 17$ \\
\hline & Tokat & $875 \pm 150$ & $263 \pm 48$ & $170 \pm 60$ & $238 \pm 48$ & $225 \pm 87$ & $275 \pm 65$ & $183 \pm 109$ & $115 \pm 44$ \\
\hline & Zonguldak & $800 \pm 216$ & $338 \pm 25$ & $323 \pm 61$ & $263 \pm 48$ & $238 \pm 25$ & $300 \pm 108$ & $243 \pm 72$ & $233 \pm 54$ \\
\hline & Average G-2 & $857.5 \pm 31.9^{*}$ & $365 \pm 30.1$ & $280.5 \pm 22.3$ & $305 \pm 21.7$ & $256 \pm 12.2^{*}$ & $353,5 \pm 24.4^{*}$ & $180 \pm 15.1$ & $163 \pm 12.12$ \\
\hline & Total average & $796 \pm 209$ & $351 \pm 104$ & $264 \pm 73$ & $285 \pm 75$ & $239 \pm 45$ & $309 \pm 82$ & $174 \pm 47$ & $163 \pm 50$ \\
\hline
\end{tabular}

*Treatment cost of abomasum displacement, retained placenta and mastitis was significantly higher for the farmers in group 2 than those in group $1(\mathrm{P}<0.05)$. $\mathrm{AD}=$ abomasum displacement, $\mathrm{RP}=$ retained placenta, $\mathrm{CO}=$ cystic ovaries, $\mathrm{Al}=$ artificial insemination

Group 1 and Group 2 were compared in terms of treatment costs. The treatment cost of abomasum displacement, retained placenta and mastitis was significantly higher for the farmers in group 2 than those in group $1(\mathrm{P}<0.05)$. Treatment cost of clinical ketosis, metritis, laminitis, cystic ovarian and artificial insemination was also an increasing tendency in group 2, but there was no significant difference $(P>0.05)$.

3.3. Slaughtered Dairy Lactating Cows by Provinces between 2017 and 2019

The number of lactating dairy cows sent to slaughter between 2017-2019 in 14 provinces with the highest dairy cows' population, was presented in Table 3 and Figure 5. The total number of slaughtered lactating dairy cows was 258596, 227452 and 295899 in 2017, 2018 and 2019 in Turkey, respectively. While the total number of slaughtered female animals decreased in 2018 (by 13.6\%), there was an increase in 2019 (by 14.4\%) compared to 2017. The increase in 2019 was observed in almost all provinces. Provinces such as Afyon, Aydın, Balıkesir, Bursa, Konya, Edirne, İzmir and Kırklareli are leading in the culling rate among others because more than 10000 lactating dairy cattle were slaughtered in those provinces in 2019.

\section{Discussion}

Annual milk production and HYDC population in Turkey had a significantly increasing trend in the last 28 years, especially after 2002. A clear transformation in dairy cattle population was observed when we analyzed the data on the TÜIK (2019) web page and in TİGEM (2017, 2018 and 2019) reports. The local indigenous breed was replaced by HYDC breeds. Although there is not a remarkable increase in the number of total lactating dairy cattle, it turned out that the domestic dairy cattle population was replaced by high milk-producing pure culture breeds.

Table 3. Number of female cows going to slaughter between 2017 and 2019 in 14 provinces with the highest dairy cows' population*

\begin{tabular}{lccc}
\hline Province & 2017 & 2018 & 2019 \\
\hline Afyon & 12268 & 12476 & 15299 \\
Antalya & 6153 & 4515 & 6093 \\
Aydın & 14942 & 13444 & 25886 \\
Balıkesir & 27821 & 14432 & 16635 \\
Burdur & 7941 & 6628 & 7512 \\
Bursa & 7457 & 10326 & 11746 \\
Çanakkale & 7657 & 8003 & 9913 \\
Denizli & 5770 & 3472 & 6334 \\
Edirne & 6363 & 6174 & 10739 \\
İzmir & 23276 & 19666 & 26139 \\
Kırklareli & 5735 & 7323 & 10040 \\
Konya & 30406 & 26094 & 29198 \\
Muğla & 6239 & 5779 & 7341 \\
Tekirdag & 8751 & 8007 & 8604 \\
\hline
\end{tabular}

*According to letter of Turkish Ministry of Agriculture and Forestry dated on 15th January 2020. 
According to TİGEM (2019) livestock report, Turkey has imported 566980 breeding cattle between 2000 and 2019 , and has paid a total of 1557927243 US dollars. The number of dairy cows that were culled and sent to slaughter across the provinces was 781947 between 2017 and 2019. There was also a significant increase in the number of animals sent to the slaughterhouse in the last 3 years. This situation is normally alarming in certain provinces especially for those having more than 10000 cullings per year. Although the number of pure culture breeds has increased significantly, milk yield during a lactation period per cow is still insufficient in Turkey compared to West European countries, except for the operation of TIGGM.

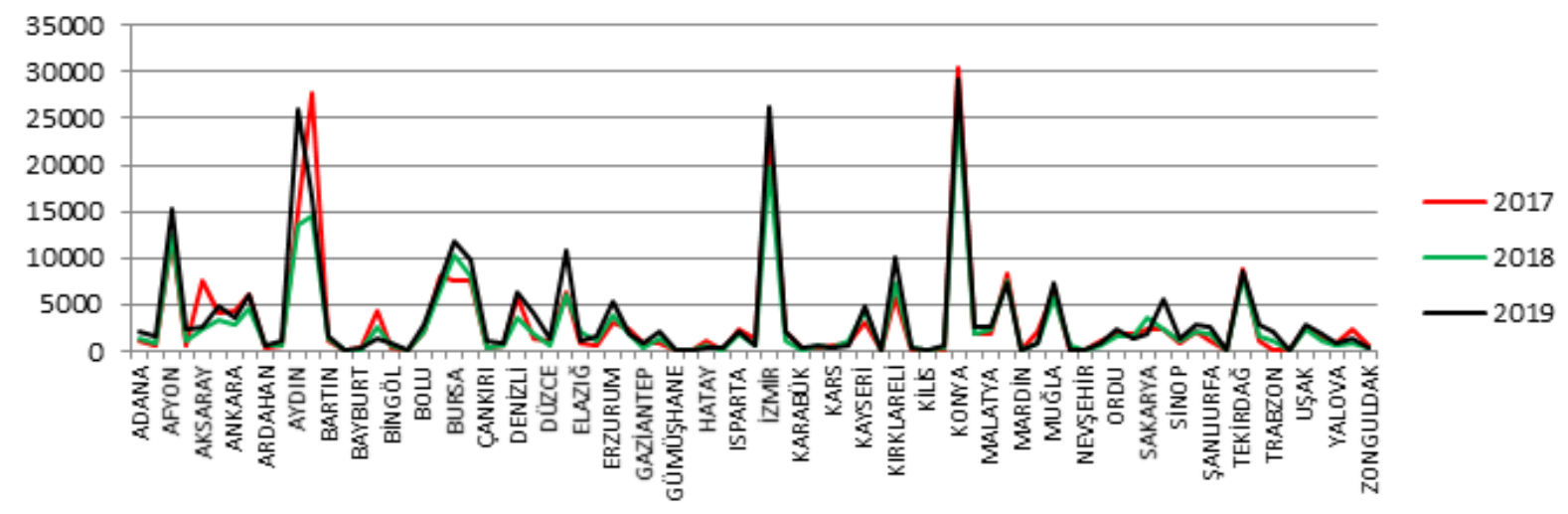

Figure 5. Number of female animals slaughtered by provinces between 2017 and 2019 .

The performance of high producing dairy cows raised in TIGEM comparable to the West European countries, this should be extended to all over Turkey to increase the amount of milk produced in lactation per animal. The reasons for this may be that the majority of dairy farming is already in the family breeding style, metabolic and reproductive diseases that develop due to feeding, management and breeding. Majority of the livestock business in Turkey appears to be a small family business style so that over $90 \%$ of the dairy farms in the early 2000s was family breeding business with 1-10 cattle (Vural and Fidan, 2007). It has been reported that dairy cow enterprises consist of $90 \%$ family business type with average of 27.8 heads and \%3 large integrated business type (Tutkun et al. 2017). In the study conducted on 95 dairy farms with at least 4 cows in farm districts of İzmir, $37.9 \%$ of the enterprises were reported to have $4-15$ dairy cows and 63\% to 4-30 dairy cows (Uzmay, 2017). This data shows that cattle farming business is still a family type small business in Turkey and need to have supports in terms of management and feeding of especially lactating dairy cattle to increase the milk production per head and to decrease the culling rate since still breeding HYDC are imported in Turkey. According to the internal profitability ratio calculations, the profitability of HYDC farming was $15.96 \%$, and $4.78 \%$ in indigenous breeds in Tokat province (Altıntaş and Akçay, 2010). Although the increase of pure culture breed in the population increases the milk production and profitability compared to indigenous breeds, it also brings at the same time important problems in terms of metabolic and reproductive diseases (Grimard et al. 2006; Korkmaz and Küplülü, 2014; Morton et al. 2016; Ülker and Bakır, 2013). In dairy cattle farming, high milk yield, maintenance and feeding conditions have been reported to be the significant cause of fertility problems (such as a decrease in conception rate) (Grimard et al. 2006). Due to the reproduction problems in HYDC, an average of $22.6 \%$ of culling cases was reported (Ülker and Bakır, 2013). According to a research finding of the cost of mastitis, a loss of 528 ( (equivalent to $310 \mathrm{~L} \mathrm{milk)}$ in a mild/moderate mastitis case was calculated, while this loss can increase to 1207 £ (equivalent to $710 \mathrm{~L}$ milk) in severe cases. When this loss was generalized to overall Turkey, a loss of $1385856000 €$ was calculated due to mastitis (Sarıözkan, 2019). Some metabolic diseases are often seen in HYDC related to energy metabolism (Drackley, 1999), significant increase of the proportion of HYDC in lactating dairy cows population in Turkey in the last 28 years will probably brought related metabolic and reproductive disorders, which might be a reason for the increasing culling rate in the last 3 years. The last 3 weeks of pregnancy and the first 3 weeks of the post-partum period is known as transition period (Deniz et al. 2020, Drackley 1999; Grummer 1995). According to Bell (1995), cows producing $30 \mathrm{~kg}$ milk daily need 2 times more amino acids, 4.5 times more fatty acids, and 2.7 times more glucose for lactation on day 4 post-calving than on day 4 pre-calving. This is a huge change and requirement for the metabolism of HYDC, which might result in NEB and associated postpartum metabolic and reproductive diseases (Deniz et al. 2020). Metabolic and reproductive diseases frequently encountered in the peripartum period in 61 herds in HYDCs are listed as follows: 7.2\% milk fever (0-44.1\%), $9 \%$ retained placenta $(0-22.9 \%), 3.3 \%$ abomasum displacement $(0-14 \%), 3.7 \%$ ketosis $(0-20 \%)$, metritis $12.8 \%(0-66 \%), 13.5 \%$ cystic ovaries $(0-58.8 \%)$ and $12.8 \%$ uterine infections $(0-66 \%)$. Complications during the transition period may be more prominent in HYDC breeds, (Fürll et al. 2010; Grimard et al. 2006; Korkmaz and Küplülü, 2014; Morton et al. 2016). Additionally, as 
found out in the present study, there is tremendous cost for the treatment of metabolic and reproductive diseases in HYDC, which is fluctuating among provinces. In that case, provinces having $>120000$ lactating dairy cows seem to be advantageous in terms of the cost for the treatment of certain metabolic and reproductive disorders. This situation might be due to the availability of enough number of patients for the veterinarian in that region, which might create a competition. However, the number of veterinarians dealing with the large animals in those regions must also be commented indeed.

\section{Conclusion}

Conclusively, this present retrospective study has indicated the clear transformation of lactating dairy cattle population from indigenous tradition breed producing low milk yield per lactation to HYDC breed producing high milk yield per lactation between 1991 and 2019. This did simultaneously increase the annual milk production from 8.6 mio tons in 1991 up to 20.7 mio tons in 2019. However, due to well-known problems in terms of genetic, management and feeding of HYDC, both early culling rate and incidence and cost of metabolic and reproductive diseases will be a costly long-term problem unless certain measures are taken. It was thought that dairy cows with high milk yield go to slaughter at an early age due to different health problems, which result in economic loss for Turkey and additional costs for the farmers.

\section{Author Contributions}

$\mathrm{KA}$ and $\mathrm{AD}$ originally conceived the idea and hypothesis. KA designed the study, and made the research organization, and collected the data. MM made the statistics and interpreted the results. $\mathrm{KA}$ and $\mathrm{AD}$ drafted the manuscript. All authors reviewed and approved the manuscript.

\section{Conflict of Interest}

The authors declare that there is no conflict of interest.

\section{Acknowledgements}

This research was presented as an oral presentation at the IV. International Congress on Domestic Animal Breeding Genetics and Husbandry - 2020 (ICABGEH-20) held on August 12-14, 2020, İzmir, Turkey.

\section{References}

Altıntaş G, Akçay Y. 2010. Tokat ili Erbaa Ovası'nda süt sığırcılığı yetiştiriciliğinin karlılığı (bir yatırım analizi örneği). Verimlilik Der, 109-128.

Bell AW. 1995. Regulation of organic nutrient metabolism during transition from late pregnancy to early lactation. J Anim Sci, 73: 2804-2819.

Correa MT, Erb H, Scarlett J. 1993. Path analysis for seven postpartum disorders of Holstein cows. J Dairy Sci, 76:13051312.

Deniz A, Aksoy K, Metin M. 2020. Transition period and subclinical ketosis in dairy cattle: Association with milk production, metabolic and reproductive disorders and economic aspects. Med Weter, 76 (9): 495-502.

Dohoo IR, Martin SW. 1984. Subclinical ketosis: Prevalence and associations with production and disease. Can J Comp Med, 48:1-5.

Drackley JK. 1999. Biology of dairy cows during the transition period: The final frontier? J Dairy Sci; 82: 2259-2273.

Fürll M, Deniz A, Westphal B, Illing C, Constable, PD. 2010. Effect of multiple intravenous injections of butaphosphan and cyanocobalamin on the metabolism of periparturient dairy cows. J Dairy Sci, 93: 4155-4164.

Görgül OS. 1988. Sığırlarda tırnak bakımı ve ayak hastalıklarının sebep ve sonuç ilişkileri. Profesörlük Takdim Tezi, Uludağ Üniv, Vet Fak, Bursa.

Grimard B, Freret S, Chevallier A, Pinto A, Ponsart C, Humblot P. 2006. Genetic and environmental factors influencing first service conception rate and late embryonic/foetal mortality in low fertility dairy herds. Anim Reprod Sci, 91: 31-44.

Grummer, RR. 1995. Impact of Changes in Organic Nutrient Metabolism on Feeding the Transition Dairy Cow. J Anim Sci, 73: 2820-2833.

İstek Ö, Durgun T. 2004. Muş ve yöresindeki sığırlarda görülen ayak hastalıklarının prevalansı üzerine araştırmalar. Doğu Anadolu Bölgesi Araş, 39-47.

Korkmaz O, Küplülü S. 2014. Yüksek süt verimli ineklerde infertilite nedenleri. Harran Üniv Vet Fak Derg, 3(1): 49-54.

Morton JM, Auldist MJ, Douglas ML, Macmillan KL. 2016. Associations between milk protein concentration, milk yield, and reproductive performance in dairy cows. J Dairy Sci, 99: 10033-10043.

Özcan S, Pamuk K. 2009. Afyonkarahisar ve çevresinde sığır ayak hastalıklarının insidansı. Kocatepe Vet J, 2(2), 15-19.

Sarıözkan S. 2019. Türkiye'de süt siğirciliği işletmelerinde mastitis nedeniyle oluşan finansal kayiplarin tahmin edilmesi. Harran Üniv Vet Fak Derg, 8 (2): 147-151.

TİGEM. 2017. 2017 Yılı hayvancıllk sektör raporu. TİGEM Sektörel Değerlendirme Raporlarl, URL: https://www.tigem.gov.tr/WebUserFile/DosyaGaleri/2018/ 2/a374cc25-acc1-44e8-a54663b4c8bce146/dosya/2017 \%20TIGEM \%20HAYVANCILIK\%20SEKTOR\%20RAPORU.pdf (access date: 17.09.2019).

TİGEM. 2018. 2018 Yılı hayvancılık sektör raporu. TİGEM Sektörel Değerlendirme Raporlarl, URL: https://www.tigem.gov.tr/DosyaGaleriData/View/a374cc25 -acc1-44e8-a546-63b4c8bce146 (accessed date: September 17, 2019).

TİGEM. 2019. 2019 Yılı hayvancılık sektör raporu. TİGEM Sektörel Değerlendirme Raporları. URL: https://www.tigem.gov.tr/WebUserFile/DosyaGaleri/2018/ 2/a374cc25acc144e8-a546 63b4c8bce146/dosya/2019\%20YILI\%20HAYVANCILIK\%20 SEKTOR\%20RAPORU.pdf (accessed date: September 17, 2019).

TÜİK. 2019. Hayvancılı istatistikleri. URL: http://www.tuik.gov.tr (accessed date: August 14, 2019).

Tutkun M, Denli M, Sessiz A. 2017. Diyarbakır ili süt sığırcılığı işletmelerinin yapısal durum analizi. TURJAF, 5(5): 476-483.

Uzmay A. 2017. Hayvancılık sektöründe uygulanan politikalarin süt siğirciliği işletmelerine etkisi üzerine üretici görüşlerinin saptanması: İzmir ili örneği. Ege Üniv Ziraat Fak Derg; 54 (2):167-175.

Ülker H, Bakır G. 2013. Culling reasons and affecting factors in a Holstein dairy herd raised in southeast region of Turkey. YYÜ Tar Bil Derg, 23(2): 134-140.

Ünsaldı E, Durmuş AS. 1999. 1994-1998 yılları arasında 
kliniğimize gelen sığırlarda gözlenen ayak hastalıkları ve sağaltımları. FÜ Sağ Bil Derg, 13, 405-412.

Vural H, Fidan H. 2007. Türkiye'de hayvansal üretim ve hayvancllık işletmelerinin özellikleri. Tarım Ekon Derg, 13(2): 49-59.

Yakan S. 2018. Ağrı ilinde siğirlarda ayak hastaliklari prevalansinin belirlenmesi. Harran Üniv Vet Fak Derg, 7 (2): 207-212.

Yayla S, Aksoy Ö, Kılıç E, Cihan M, Özaydın İ, Ermutlu CŞ. 2012.
Kars ve yöresinde sığırların bakım ve barındırma koșulları ile ayak hastalıkları arasındaki ilişkinin değerlendirilmesi. Harran Üniv Vet Fak Derg, 1(1), 22-27.

Yurdakul İ, Şen İ. 2018. Sivas ve yöresinde sığır ayak hastalıkları prevalansının belirlenmesi. Harran Üniv Vet Fak Derg, 7(1), 51-55.

Whitaker DA, Smith EJ, da Rosa GO, Kelly JM. 1993. Some effects of nutrition and management on the fertility of dairy cattle. Vet Rec, 133:61-64. 